Article Type: Research Paper

\title{
Can Assets Determine Family Happiness?
}

\author{
Vitriyani Tri Purwaningsih
}

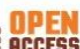

\section{AFFILIATION:}

Master of Science in Economics, Faculty of Economics and Business, Universitas Gadjah Mada, Special Region of Yogyakarta, Indonesia

\section{*CORRESPONDENCE:}

vitriyanitp@gmail.com

THIS ARTICLE IS AVAILABLE IN:

http://journal.umy.ac.id/index.php/jerss

DOI: $10.18196 /$ jerss.v5i2.12455

\section{CITATION:}

Purwaningsih, V.T. (2021). Can Assets Determine Family Happiness?. Journal of Economics Research and Social Sciences, 5(2), 156-166.

\begin{abstract}
Ownership of assets can be assessed as the success of individual achievement in his life goals. It certainly can make individuals feel satisfied with the efforts they have made. Life satisfaction is one of the dimensions used by BPS to measure happiness. Thus, this study will analyze the effect of asset ownership on happiness. The data used in this study are data from the Indonesia Family Life Survey (IFLS) wave 5 of 2014. Analysis of the model in this study uses logistic regression for analysis in Java and outside Java Island. This study found that ownership of assets (jewelry, savings, vehicles, receivables), health, gender of the head of the household, type of residential, mobile phone, television, and access to the internet have a significant effect on household happiness. At the same time, other assets (houses/other buildings, land), number of household members, type of floor, and residential area (urban, rural) have no effect in determining of happiness of the household. The finding in this study also states that the probability of household happiness will be higher outside Java Island.
\end{abstract}

Keywords: Assets; Happiness; Household; Java

JEL Classification: D14, O18, R13

\section{Introduction}

Every individual and even household will want a happy life. In determining what can make you happy, of course, everyone has their criteria. For example, some people judge that happiness is simple when you can gather with your family. On the other hand, some people think that happiness is simple when you can buy things using your salary from work. Every meaning of happiness understood by each person is considered normal when happiness is not obtained by harming others.

Happiness can be interpreted as a feeling of pleasure and satisfaction with something (Kahneman, Diener, \& Schwarz, 1999). Happiness can also be interpreted as an evaluation of the life felt by a person towards certain aspects of life as well as his life as a whole by also considering feelings that include the emotional experienced, and eudaimonia that refers to the psychological function of someone who can walk well (NEF, 2011; Clark \& Senik, 2011; Deci \& Ryan, 2006). Piekałkiewicz (2017) argues that happiness can be an economic concept that can critically review the economic application of happiness data and the economic consequences. Happiness can act as a determinant of economic outcomes such as increasing productivity, predicting one's income in the future, and influencing performance in the labor market. 
In empirical studies, the level of happiness can be measured through several indicators. For example, BPS (2017) assesses happiness based on a framework that includes three dimensions of life: life satisfaction, feelings, and meaning. Based on the results of these measurements, the average happiness level of Indonesian in 2017 was 70.69 on a scale of $0-100$. The three provinces that have the highest happiness index are North Maluku (75.68), Maluku (73.77), and North Sulawesi (73.69). In comparison, the three provinces with the lowest happiness index are East Nusa Tenggara (68.98), North Sumatra (68.41), and Papua (67.52) (BPS, 2017).

Some researchers interpret happiness as perceived by efforts to achieve something that is dreamed of the potential and purpose of one's life (Franklin, 2010; Martin, 2012). One that can be considered as achievement is a position. Someone feels happy when he tries to get a good position at work. Then his efforts are successfully obtained. In addition, assets can also be said to achieve one's life goals. People who work get a wage, then part of their income is used for savings, undoubtedly because of certain motives or goals. Usually, the savings are used for savings or assets, both for short-term and longterm purposes. In addition, usually, some people also have assets in the form of houses or land.

Zhang, Zhang, and Hudson (2018) analyze housing conditions on individual life satisfaction in urban China. With the probit model, empirical results show that homeownership and home size play an important role in determining overall happiness. In China, women value housing for a home more than men (Huang et al., 2015). For women, homeownership positively affects overall satisfaction and happiness in urban China (Hu, 2013). In addition, older generations and high-income people have higher life satisfaction when they have a home.

The house is the most important basic human need as a place to live. In addition, the house is considered an essential household asset, and homeownership by women is considered an asset that reflects the social status of married women. Therefore, assets become an essential component in the marital tradition in Indonesia because the presence of a portion of women's assets will determine the allocation of expenditure (Pangaribowo, Tsegai, \& Sukamdi, 2018). Furthermore, the latest research in Indonesia conducted by Kurniawan and Samir (2019), assets owned by women can reflect their economic status, so that these assets will affect the dowry value that will be received when they get married.

Happiness is usually influenced by how wealthy a person is and in terms of health and other factors. Rogers and Zaragoza-Lao (2003) conduct studies on children's health in Ohio. The analysis results concluded that it would be more likely to have healthy children with recreation to grow up happier. Happiness felt by family members, especially children, will undoubtedly impact the happiness of parents and all household members. As such, it can be said implicitly that entertainment and health are essential for achieving happiness. Some researchers also found that most of the individual and household characteristic variables have a significant factor in determining satisfaction 
(Hu, 2013; Knight, Song, \& Gunatilaka, 2009; Knight \& Gunatilaka, 2011; Wang \& VanderWeele, 2010; Zhang et al., 2018).

Homeowners have a higher sense of ownership and can choose the closest education for their children to increase the likelihood of satisfaction at home (Huang et al., 2015). In contrast to Cheng et al. (2016), who found that although homeownership was positively correlated with life satisfaction, in this study, the magnitude of influence depends on the type of homeownership. In addition to homeownership, Oswald et al. (2003) state that housing conditions also affect parents' life satisfaction in rural Germany. Financial assets, tangible assets, and their changes also have a significant relationship with the happiness of a wife's marriage with her husband (Han \& Kim, 2014). The findings of this study underline the importance of assets for marital happiness.

Therefore, this study intends to analyze whether assets can determine household happiness in Indonesia. This study will divide the household into two parts: households living on the island of Java and households living not on the island of Java. The main contribution of this research is that some of the assets that are the focus for analysis are land and houses occupied by households, land (such as vacant land, land not for business, and others), and houses or other buildings owned by households. The three forms of assets are almost similar but differ in terms of usability. Thus, this study will analyze the three forms of assets, which might contribute to household happiness in Java and outside Java. In addition to these assets, other assets such as jewelry, savings, vehicles, and receivables will be analyzed.

The structure of this research will be divided into several sections that need attention. After writing the background in the first section, the next section will explain the research methods and data used as research samples in Section 2. Next, Section 3 will provide the results of the research. Finally, the last part of this research is the conclusion that summarizes the overall topic of this research and references used in this paper.

\section{Research Method}

This study uses secondary data sourced from the 2014 Indonesia Family Life Survey (IFLS) so that the research data is cross-sectional. The IFLS is a large-scale household and community survey that covers the living conditions of people in some provinces in Indonesia. The 2014 IFLS data is the fifth wave of more than 15,000 households and more than 50,000 individuals spread across 24 rural and urban provinces. Provinces in IFLS 5 wave data include: Aceh, North Sumatra, West Sumatra, Riau, Jambi, South Sumatra, Lampung, Bangka Belitung Islands, Riau Islands, Special Capital Region of Jakarta, West Java, Central Java, Special Region of Yogyakarta , East Java, Banten, Bali, West Nusa Tenggara, West Kalimantan, Central Kalimantan, South Kalimantan, East Kalimantan, South Sulawesi, West Sulawesi and Papua. 
The unit of analysis observed in this research is household happiness which is influenced by various factors. As for determining the level of household happiness, refer to Book $3 \mathrm{~A}$, wherein the welfare section has a question "Considering the current situation, do you feel delighted, happy, unhappy or very unhappy?". Based on the questionnaire answers, this study uses a dummy variable with a value of 1 when the respondent answers "delighted" or "happy" and a value of 0 when the respondent answers "very unhappy" or "unhappy."

There have been many empirical studies that discuss happiness, and even the Central Statistics Agency has macro data on the index of happiness in Indonesia. However, this research model refers to the study of Zhang et al. (2018) with some variables with various considerations, which also refers to other studies (such as Wu et al., 2019; Oswald et al., 2003; Hu, 2013 and others). In addition, this research will be observed separately into several models. The first model will analyze households in Java Island (such as Banten, Special Capital Region of Jakarta, West Java, Central Java, East Java, and Special Region of Yogyakarta). Next, in the second model, the analysis will be conducted on households outside Java (provinces that are not in Java Island). Thus the equation model of this research is as follows:

$$
H P N_{i}=\beta_{0}+\beta_{1} A S_{i}+\beta_{2} T H_{i}+\beta_{3} D H_{i}+\beta_{4} M E_{i}+\varepsilon_{i}
$$

With $H P N$ as the dependent variable, which is the level of happiness. Variable $A S, T H$, $D H$ and $M E$ is an independent variable. Each of which includes assets owned by households (houses and land occupied, houses/other buildings, land, vehicles, savings, jewelry, receivables), house characteristics (building type, floor type), characteristics of household (age of head of the family, gender of head of the family, health, area of residence, number of family members) and household access to media/other exposure (internet, electricity, television and mobile phone). Thus, because the dependent variable is a dummy, the logistic regression model will be used in this study based on $\mathrm{Wu}$ et al. (2019).

\section{Result and Discussion}

In the data and methodology section previously, variables have been defined which will be used in this study. After collecting the required data, the number of observations was as many as 10,685 households in Indonesia, where $44.01 \%$ and $55.99 \%$ were rural and urban households, respectively. In addition to urban and rural areas as a regional form, observations are grouped into Java and outside Java regions. Figure 1 shows that $53.38 \%$ or 5,704 households were in Java, and $46.62 \%$ or 4,981 households were observed outside the Java region. The main focus of this research is to look at the effect of asset ownership on household happiness. In Figure 2, it can be seen that the assets most owned by households are vehicles $(85.7 \%)$, houses/land occupied $(78.66 \%)$, jewelry $(55.73 \%)$, and savings (30.62\%). Vehicles become a necessary transportation tool for all households because vehicles are usually used for transportation to schools, offices, or other activities. 


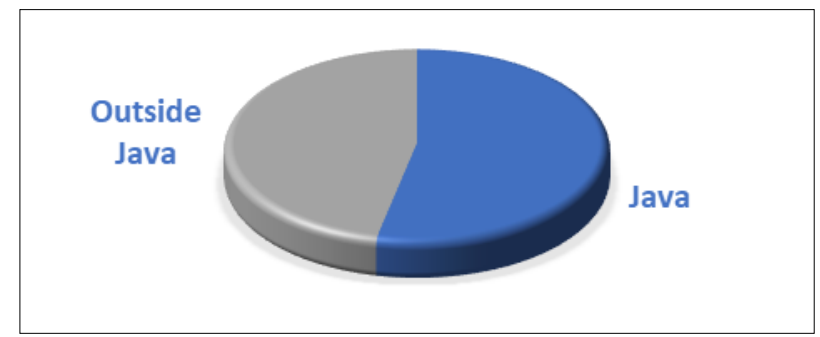

Figure 1 Percentage of households by region

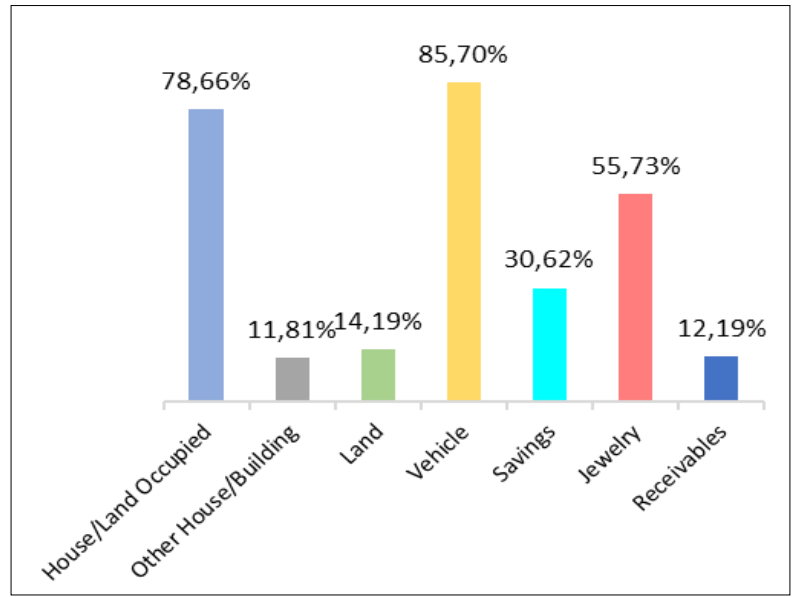

Figure 2 Percentage of households assets

In the data and methodology section previously, variables have been defined which will be used in this study. After collecting the required data, the number of observations was as many as 10,685 households in Indonesia, where $44.01 \%$ and $55.99 \%$ were rural and urban households, respectively. In addition to urban and rural areas as a regional form, observations are grouped into Java and outside Java regions. Figure 1 shows that $53.38 \%$ or 5,704 households were in Java, and $46.62 \%$ or 4,981 households were observed outside the Java region. The main focus of this research is to look at the effect of asset ownership on household happiness. In Figure 2, it can be seen that the assets most owned by households are vehicles (85.7\%), houses/land occupied (78.66\%), jewelry $(55.73 \%)$, and savings (30.62\%). Vehicles become a necessary transportation tool for all households because vehicles are usually used for transportation to schools, offices, or other activities.

Moreover, many financial institutions offer loans or credit so that financially limited households can still have a vehicle. As a result, even today, the average vehicle owned in a household can be more than one unit, where each household member has their vehicle. Of the several types of household assets, land (14.19\%), receivables (12.19\%), and other buildings $(11.81 \%)$ are the least commonly owned because only certain household groups have more income who usually owns these assets.

Table 1 shows that the average age of household heads is 46 years old, and also the average number of household members in Indonesia is four people in one family. The 
majority of the regions included in the analysis of this study were the Java region. Table 1 also shows the averages for dummy variables that can be expressed in terms of percentage points. As with happiness with an average value of 0.91 , it can be interpreted that respondents who entered into the analysis of this study $91 \%$ felt their lives were currently happy, and health was valued at 0.78 , which means that on average, $78 \%$ of households felt themselves in good health. The sex of the head for the majority of respondents is male (96\%). It is because, in general, the household is led by a man.

Today, an average of $99 \%$ of households already use electricity in their homes, and an average household already has a television (93\%) and mobile phones (70\%), while households that use the internet are still relatively low at only around $22 \%$. Households that were the unit of analysis in this study lived on average in urban areas (56\%). On average, the type of building they occupy is not multi-story, where only $13 \%$ of households live in multi-story buildings. Not only the type of building, but this study also looked at the type of flooring of the household, and the result was that, on average, $83 \%$ of households had used solid floorings such as ceramics, marble, tiles, and others.

Table 1 Descriptive statistics

\begin{tabular}{lc}
\hline \multicolumn{1}{c}{ Variable } & Mean (SD) \\
\hline Age & $45.83(12.98)$ \\
Num. of Household Member & $4.47(1.78)$ \\
Region & $1.47(0.50)$ \\
Happiness & $0.91(0.28)$ \\
Gender & $0.96(0.19)$ \\
Health & $0.78(0.41)$ \\
Mobile phone & $0.70(0.46)$ \\
Internet & $0.22(0.41)$ \\
Area (Urban-Rural) & $0.56(0.50)$ \\
Type of Residential & $0.13(0.34)$ \\
Type of Floor & $0.87(0.34)$ \\
Electricity & $0.99(0.00)$ \\
Television & $0.93(0.26)$ \\
\hline
\end{tabular}

Based on the Table 2, the results of this analysis state that for regions in Java, all the factors in this study can affect the happiness of rural and urban households in Java. The effect of ownership of houses/land is not significant. Meanwhile, other assets such as vehicles, jewelry, savings, and receivables positively affect the happiness of households in Java. However, there are some insignificant variables, namely other houses/buildings, land, residential area, number of household members, and floor type.

Table 2, the result of analysis for outside Java regions, shows that the effect of ownership of houses/land occupied positively affects households' happiness, and the age of the household head negatively affects the happiness of households outside Java. The rest of asset variables (vehicle, savings, jewelry, receivable), internet, mobile phone, television, type of residential, health, and gender of household heads positively determine household happiness. Thus, the overall results of Table 2 show that ownership of assets can determine the happiness of households in Java and outside Java. 
Table 2 Analysis Logistic Regression: Happiness in Java and Outside Java

\begin{tabular}{|c|c|c|}
\hline Variable & Java & Outside Java \\
\hline \multirow[t]{2}{*}{ House and Land Occupied } & 0.121 & $0.300^{* *}$ \\
\hline & $(0.137)$ & $(0.136)$ \\
\hline \multirow[t]{2}{*}{ Other House/Building } & 0.152 & 0.212 \\
\hline & $(0.173)$ & $(0.193)$ \\
\hline \multirow[t]{2}{*}{ Land } & 0.112 & 0.201 \\
\hline & $(0.153)$ & $(0.169)$ \\
\hline \multirow[t]{2}{*}{ Vehicle } & $0.269^{* *}$ & $0.337^{* * *}$ \\
\hline & $(0.128)$ & $(0.128)$ \\
\hline \multirow[t]{2}{*}{ Savings } & $0.301^{* *}$ & $0.460^{* * *}$ \\
\hline & $(0.122)$ & $(0.167)$ \\
\hline \multirow[t]{2}{*}{ Jewelry } & $0.277^{* * *}$ & $0.273^{* *}$ \\
\hline & (0.0997) & (0.119) \\
\hline \multirow[t]{2}{*}{ Receivables } & $0.398^{* *}$ & $0.456^{*}$ \\
\hline & $(0.191)$ & $(0.234)$ \\
\hline \multirow[t]{2}{*}{ Age } & $-0.00806^{*}$ & $-0.0201^{* * *}$ \\
\hline & $(0.00412)$ & $(0.00457)$ \\
\hline \multirow[t]{2}{*}{ Gender } & $0.667^{* * *}$ & $0.738^{* * *}$ \\
\hline & $(0.193)$ & $(0.227)$ \\
\hline \multirow[t]{2}{*}{ Health } & $0.906^{* * *}$ & $0.986^{* * *}$ \\
\hline & $(0.102)$ & $(0.111)$ \\
\hline \multirow[t]{2}{*}{ Internet } & $0.735^{* * *}$ & $0.430^{* *}$ \\
\hline & $(0.194)$ & $(0.206)$ \\
\hline \multirow[t]{2}{*}{ Area } & 0.0961 & 0.171 \\
\hline & $(0.104)$ & (0.119) \\
\hline \multirow[t]{2}{*}{ Type of Residential } & $0.376^{* *}$ & $0.456^{* *}$ \\
\hline & (0.189) & $(0.177)$ \\
\hline \multirow[t]{2}{*}{ Electricity } & $1.530^{*}$ & -0.0137 \\
\hline & $(0.792)$ & $(0.426)$ \\
\hline \multirow[t]{2}{*}{ Television } & $0.608^{* * *}$ & $0.436^{* * *}$ \\
\hline & $(0.187)$ & $(0.152)$ \\
\hline \multirow[t]{2}{*}{ Num. of Household Member } & -0.0202 & -0.0172 \\
\hline & $(0.0270)$ & $(0.0277)$ \\
\hline \multirow[t]{2}{*}{ Mobile phone } & $0.488^{* * *}$ & $0.413^{* * *}$ \\
\hline & $(0.117)$ & $(0.128)$ \\
\hline \multirow[t]{2}{*}{ Type of Floor } & 0.217 & -0.0173 \\
\hline & $(0.165)$ & $(0.146)$ \\
\hline$N$ & 5704 & 4981 \\
\hline
\end{tabular}

Note : () standard errors, ${ }^{*} p<0.1,{ }^{* *} p<0.05,{ }^{* * *} p<0.01$

Table 3 shows the average marginal effect of the analysis of households in Java and outside Java. The estimation results in the table explain the effect of the change coefficient of each independent variable on the dependent variable. By involving control variables, ownership of assets, especially houses and land occupied, has a significant effect when households are outside Java.

When a household outside Java has a house and land occupied, the probability of happiness will increase by about 0.02 . Other asset ownership factors that significantly 
influence household happiness in Java and outside Java are vehicles, jewelry, receivables, and savings. For example, for households in Java, owning vehicle assets, jewelry and savings will increase the probability of happiness by 0.02 . Nevertheless, for households outside Java, vehicles and jewelry can increase their probability of happiness by 0.02 , respectively, while savings and receivables are higher in their probability of increasing happiness by 0.03 each. These results prove that assets can influence the probability of happiness in line with several previous studies (such as Zhang et al., 2018; Han \& Kim, 2014).

Table 3 Marginal Effect: Happiness in Java and Outside Java

\begin{tabular}{|c|c|c|}
\hline Variable & Java & Outside Java \\
\hline \multirow[t]{2}{*}{ House and Land Occupied } & 0.00960 & $0.0208^{* *}$ \\
\hline & (0.0109) & (0.00948) \\
\hline \multirow[t]{2}{*}{ Other House/Building } & 0.0121 & 0.0147 \\
\hline & $(0.0138)$ & $(0.0134)$ \\
\hline \multirow[t]{2}{*}{ Land } & 0.00893 & 0.0139 \\
\hline & $(0.0122)$ & $(0.0117)$ \\
\hline \multirow[t]{2}{*}{ Vehicle } & $0.0214^{* *}$ & $0.0234^{* * *}$ \\
\hline & $(0.0102)$ & $(0.00890)$ \\
\hline \multirow[t]{2}{*}{ Savings } & $0.0240^{* *}$ & $0.0319^{* * *}$ \\
\hline & $(0.00971)$ & $(0.0116)$ \\
\hline \multirow[t]{2}{*}{ Jewelry } & $0.0221^{* * *}$ & $0.0189^{* *}$ \\
\hline & $(0.00795)$ & $(0.00825)$ \\
\hline \multirow[t]{2}{*}{ Receivables } & $0.0316^{* *}$ & $0.0316^{*}$ \\
\hline & $(0.0152)$ & $(0.0162)$ \\
\hline \multirow[t]{3}{*}{ Age } & - & $-0.00140^{* * * *}$ \\
\hline & $0.000641^{*}$ & \\
\hline & $(0.000328)$ & $(0.000319)$ \\
\hline \multirow[t]{2}{*}{ Gender } & $0.0531^{* * *}$ & $0.0512^{* * *}$ \\
\hline & $(0.0154)$ & $(0.0158)$ \\
\hline \multirow[t]{2}{*}{ Health } & $0.0721^{* * *}$ & $0.0684^{* * *}$ \\
\hline & $(0.00809)$ & $(0.00781)$ \\
\hline \multirow[t]{2}{*}{ Internet } & $0.0584^{* * *}$ & $0.0298^{* *}$ \\
\hline & $(0.0155)$ & $(0.0143)$ \\
\hline \multirow[t]{2}{*}{ Area } & 0.00764 & 0.0118 \\
\hline & $(0.00828)$ & $(0.00830)$ \\
\hline \multirow[t]{2}{*}{ Type of Residential } & $0.0299^{* *}$ & $0.0316^{* *}$ \\
\hline & $(0.0151)$ & $(0.0123)$ \\
\hline \multirow[t]{2}{*}{ Electricity } & $0.122^{*}$ & -0.000949 \\
\hline & $(0.0630)$ & $(0.0296)$ \\
\hline \multirow[t]{2}{*}{ Television } & $0.0484^{* * *}$ & $0.0302^{* * *}$ \\
\hline & (0.0149) & $(0.0105)$ \\
\hline \multirow[t]{2}{*}{ Num. of Household Member } & -0.00161 & -0.00119 \\
\hline & $(0.00215)$ & $(0.00192)$ \\
\hline \multirow[t]{2}{*}{ Mobile phone } & $0.0388^{* * *}$ & $0.0287^{* * *}$ \\
\hline & $(0.00932)$ & (0.00897) \\
\hline \multirow[t]{2}{*}{ Type of Floor } & 0.0173 & -0.00120 \\
\hline & $(0.0131)$ & $(0.0101)$ \\
\hline$N$ & 5704 & 4981 \\
\hline
\end{tabular}

Note : () standard errors, ${ }^{*} p<0.1,{ }^{* *} p<0.05,{ }^{* * *} p<0.01$ 
The age of the head of the household is quite influential in determining the level of happiness of his family. Outside Java, increasing the age of the head of the household can reduce the probability of family happiness by 0.001 , while in Java, only around 0,0007 . It can mean that people in Java and outside Java are happier when the head of the household is still young. This result is in line with previous research, as in $\mathrm{Hu}$ (2013). Younger household heads may bring a more comfortable atmosphere in the house, and with the conditions that are still young, many things can be done with his family. When households are led by men, where men are responsible for supporting their families, the probability of happiness will increase by 0.05 , both in Java and outside Java. In addition to being led by men and younger ages, households will increase their probability if the head of the household is also healthy. The health of the household head will increase happiness by about 0.07 in households in Java and outside Java. These findings are in line with the findings of the study Rogers and Zaragoza-Lao (2003).

The health of the head of the household is quite important because, with a healthy body, the head of the family can do his job well to provide for his family. In this era, electricity is vital for life because almost all tools and goods need electricity. However, the use of electricity has no significant impact on all households. In Java, households that use electricity can increase their happiness probability by $0.1 \%$. The influence of electricity is relatively strong when we see that in Java, the activities of the people are dense, the majority of business centers are in Java, so electricity is crucial for the people in Java. However, it is different from households outside Java, that electricity does not affect the probability of their happiness level.

Internet use can increase the probability of happiness higher for households in Java $(0.05)$ when compared to the probability in the outside Java region (0.03). In addition, ownership of television and mobile phones can increase the probability of happiness of households in Java $(0.05 ; 0.04$, respectively) higher than households outside Java (0.03, respectively). These findings suggest that media exposure as a form of entertainment can increase the probability of happiness, in line with research Rogers and Zaragoza-Lao (2003).

Another factor that might influence the level of happiness of households in Java and outside Java is the type of house. The type of building in which the level is occupied or not is predicted to affect household happiness. From the estimation results, Table 3 shows that if the building occupied is stratified, and it can increase the probability of household happiness by 0.03. It is in line with Azimi and Esmaeilzadeh's (2017) research, who discovered that the type and characteristics of housing could influence satisfaction. 


\section{Conclusion}

There are various definitions of happiness according to each person. For statistical measurement, BPS has three dimensions: assessment of happiness, namely the dimension of life satisfaction, the dimension of feelings, and the dimension of meaning in life. The difference between this research and existing research is that the variable ownership of assets used not only houses but also several assets that are asked in the IFLS questionnaire. In addition, this research also differs in terms of the model used. The findings of this study are pretty interesting, where the results found that the area of residence (rural/urban) has no effect in determining the level of household happiness.

In addition, these findings are also quite interesting because the ownership of houses and land occupied affects the happiness of households outside Java, but not to households in Java. It means that living in your land and house is not very important in determining the happiness of a household in Java. Other factors that positively influence household happiness are ownership of assets (jewelry, savings, vehicles, receivables), health, gender of the head of the household, type of residential, region, ownership of mobile phones, television, and internet usage. The age of household heads and the number of household members negatively affect household happiness, but only the age of household heads has a significant effect. It is possible that this research still has many limitations. Therefore, recommendations for future studies are considering the latest research, the selection of variables, the measurements, and methods to be more precise and relevant.

\section{References}

Azimi, N., \& Esmaeilzadeh, Y. (2017). Assessing the relationship between house types and residential satisfaction in Tabriz, Iran. International Journal of Urban Sciences, 21(2), 185203. https://doi.org/10.1080/12265934.2016.1273128

Cheng, Z., King, S. P., Smyth, R., \& Wang, H. (2016). Housing property rights and subjective wellbeing in urban China. European Journal of Political Economy, 45, 160-174. https://doi.org/10.1016/i.ejpoleco.2016.08.002

Clark, E., \& Senik, C. (2011). Is happiness different from flourishing? Cross-country evidence from the ESS. Revue D'économie Politique, 121(1), 17-34. https://doi.org/10.3917/redp.211.0017

Deci, E. L., \& Ryan, R. M. (2006). Hedonia, eudaimonia, and well-being: An introduction. Journal of Happiness Studies, 9(1), 1-11. https://doi.org/10.1007/s10902-006-9018-1

Franklin, S. S. (2010). The psychology of happiness. Cambridge University Press.

Han, C., \& Kim, S. J. (2014). Assets and a wife's marital satisfaction in Korea. Asia Pacific Joumal of Social Work and Development, 24(4), 251-264. https://doi.org/10.1080/02185385.2014.925817

Hu, F. (2011). Homeownership and subjective wellbeing in urban China: Does owning a house make you happier? Social Indicators Research, 110(3), 951-971. https://doi.org/10.1007/s11205-011-9967-6

Huang, Z., Du, X., \& Yu, X. (2015). Home ownership and residential satisfaction: Evidence from Hangzhou, China. Habitat International, 49, 74-83. https://doi.org/10.1016/i.habitatint.2015.05.008 
Kahneman, D., Diener, E., \& Schwarz, N. (Eds.). (1999). Well-being: The foundations of hedonic psychology. Russell Sage Foundation.

Knight, J., \& Gunatilaka, R. (2011). Does economic growth raise happiness in China? Oxford Development Studies, 39(1), 1-24. https://doi.org/10.1080/13600818.2010.551006

Knight, J., Song, L., \& Gunatilaka, R. (2009). Subjective well-being and its determinants in rural China. China Economic Review, 20(4), 635-649. https://doi.org/10.1016/i.chieco.2008.09.003

Kurniawan, R., \& Samir, S. (2019). Determinan Nilai Mahar Perkawinan: Temuan dari Indonesia Family Life Survey (IFLS) East. Retrieved from https://logovcelebes.id/publikasi/artikel/item/52-determinan-nilai-maharperkawinan-temuan-dari-indonesia-family-life-survey-ifls-east

Martin, M. W. (2012). Happiness and the good life. Oxford University Press.

New Economic Foundation (NEF). (2011). Measuring our progress the power of wellbeing. New Economic Foundation. Retrieved from https://neweconomics.org/2011/02/measuring-our-progress

Oswald, F., Wahl, H.-W., Mollenkopf, H., \& Schilling, O. (2003). Housing and life satisfaction of older adults in two rural regions in Germany. Research on Aging, 25(2), 122-143. https://doi.org/10.1177/0164027502250016

Pangaribowo, E. H., Tsegai, D., \& Sukamdi. (2018). Women's bargaining power and household expenditure in Indonesia: The role of gender-differentiated assets and social capital. GeoJournal, 84(4), 939-960. https://doi.org/10.1007/s10708-018-9901-4

Piekałkiewicz, M. (2017). Why do economists study happiness? The Economic and Labour Relations Review, 28(3), 361-377. https://doi.org/10.1177/1035304617717130

Rogers, M. A. M., \& Zaragoza-Lao, E. (2003). Happiness and children's health: An investigation of art, entertainment, and recreation. American Journal of Public Health, 93(2), 288-289. https://doi.org/10.2105/ajph.93.2.288

Statistics Indonesia (BPS). (2017). Indeks kebahagiaan. Publikasi katalog: 4102024. Retrieved from https://www.bps.go.id/publication/2017/12/05/1f99cefd596c449b93405fcd/indeks -kebahagiaan-2017.html

Wang, P., \& VanderWeele, T. J. (2010). empirical research on factors related to the subjective well-being of Chinese urban residents. Social Indicators Research, 101(3), 447-459. https://doi.org/10.1007/s11205-010-9663-y

Wu, W., Stephens, M., Du, M., \& Wang, B. (2019). Homeownership, family composition and subjective wellbeing. Cities, 84, 46-55. https://doi.org/10.1016/i.cities.2018.07.004

Zhang, F., Zhang, C., \& Hudson, J. (2018). Housing conditions and life satisfaction in urban China. Cities, 81, 35-44. https://doi.org/10.1016/i.cities.2018.03.012 